\title{
Herbicide subdoses as growth regulators in soybean cultivars
}

\author{
Subdoses de herbicidas como reguladores de crescimento em cultivares de soja \\ Subdoses de herbicidas como reguladores del crecimiento en cultivares de soja
}

Received: 01/12/2022 | Reviewed: 01/20/2022 | Accept: 01/27/2022 | Published: 01/28/2022

\author{
Tayná Alves Pereira \\ ORCID: https://orcid.org/0000-0002-6839-0127 \\ Universidade Federal do Tocantins, Brazil \\ E-mail: taynasap@gmail.com \\ Álvaro José Gomes de Faria \\ ORCID: https://orcid.org/0000-0002-2817-5908 \\ Universidade Federal de Lavras, Brazil \\ E-mail: ajgomesdefaria@ hotmail.com \\ Rubson da Costa Leite \\ ORCID: https://orcid.org/0000-0002-3572-7600 \\ Universidade Federal Rural da Amazônia, Brazil \\ E-mail: rubsonif@gmail.com \\ Antônio Henrique Camilo Ribeiro \\ ORCID: https://orcid.org/0000-0002-8646-8098 \\ Máxima Consultoria, Pesquisa e Inovação, Brazil \\ E-mail: antonio@maximato.com.br \\ Antônio Carlos Martins dos Santos \\ ORCID: https://orcid.org/0000-0002-2988-6306 \\ Instituto Federal de Educação, Ciência e Tecnologia do Pará, Brasil \\ E-mail: antoniocarlos.uft@hotmail.com \\ Jose Paulo Oliveira de Castro \\ ORCID: https://orcid.org/0000-0002-6265-5673 \\ Máxima Consultoria, Pesquisa e Inovação, Brazil \\ E-mail: josepaulo@maximato.com.br \\ Simone Pereira Teles \\ ORCID: https://orcid.org/0000-0002-8974-0288 \\ Universidade Federal do Tocantins, Brazil \\ E-mail: simonypxe@gmail.com \\ Rubens Ribeiro da Silva \\ ORCID: https://orcid.org/0000-0003-3791-2014 \\ Universidade Federal do Tocantins, Brazil \\ E-mail: rrs2002@mail.uft.edu.br
}

\begin{abstract}
The use of growth regulators through the herbicide subdoses is a promising alternative capable of reducing the size of plants, making them more compact and photosynthetically more active and efficient. The objective was to evaluate the effect of herbicide application on the development and production components of six soybean cultivars. The experiment was conducted in field under randomized blocks with four replications. Six soybean cultivars (M8644 IPRO, M8372 IPRO, M8349 IPRO and M8766 RR, NS7901 RR and CD251 RR) were submitted the application of three herbicides and their respective subdoses (2,4-D - $40.3 \mathrm{~g} \mathrm{ha}^{-1}$; Imazetapir - $26.5 \mathrm{~g} \mathrm{ha}^{-1}$ and Lactofen $\left.-96 \mathrm{~g} \mathrm{ha}^{-1}\right)$. An additional treatment without the application of any herbicide was also evaluated (Control treatment). Subdoses of 2,4-D, Lactofen and Imazetapyr provided greater plant height, height of insertion of the first pod, branches per plant, number of pods and number of grains. A new adequacy in the doses of 2,4-D, Lactofen and Imazetapyr is necessary to contribute in the future to increase the productivity of soybean.
\end{abstract}

Keywords: Glycine max; 2,4-D; Lactofen; lmazetapyr.

\section{Resumo}

A utilização de reguladores de crescimento através de subdoses herbicidas é uma alternativa promissora capaz de reduzir o tamanho das plantas, tornando-as mais compactas e fotossinteticamente mais ativas e eficientes. Objetivouse avaliar o efeito da aplicação de herbicidas sobre o desenvolvimento e componentes de produção de seis cultivares de soja. A experiência foi conduzida em campo sob blocos aleatorizados com quatro réplicas. Seis cultivares de soja (M8644 IPRO, M8372 IPRO, M8349 IPRO e M8766 RR, NS7901 RR e CD251 RR) foram submetidos à aplicação de três herbicidas e suas respectivas subdoses (2,4-D - 40,3 $\mathrm{g} \mathrm{ha}^{-1}$; Imazetapir - 26,5 $\mathrm{g} \mathrm{ha}^{-1}$ e Lactofen - $\left.96 \mathrm{~g} \mathrm{ha}^{-1}\right)$. Também foi avaliado um tratamento adicional sem a aplicação de qualquer herbicida (Tratamento controle). Subdoses de 2,4-D, Lactofen e Imazetapir proporcionaram maior altura das plantas, altura de inserção da primeira vagem, ramos 
por planta, número de vagens e número de grãos. Uma nova adequação nas doses de 2,4-D, Lactofen e Imazetapir é necessária para contribuir no futuro para aumentar a produtividade da soja.

Palavras-chave: Glycine max; 2,4-D; Lactofen; Imazetapir.

\section{Resumen}

El uso de reguladores de crecimiento a través de subdoses herbicidas es una alternativa prometedora capaz de reducir el tamaño de las plantas, haciéndolas más compactas y fotosintéticamente más activas y eficientes. El objetivo fue evaluar el efecto de la aplicación de herbicidas en los componentes de desarrollo y rendimiento de seis cultivares de soja. El experimento se realizó en campo bajo bloques al azar con cuatro repeticiones. Seis cultivares de soja (M8644 IPRO, M8372 IPRO, M8349 IPRO y M8766 RR, NS7901 RR y CD251 RR) fueron sometidos a la aplicación de tres herbicidas y sus respectivas subdosis (2,4-D - 40,3 $\mathrm{g} \mathrm{ha}^{-1}$; Imazetapir - 26,5 $\mathrm{g} \mathrm{ha}^{-1} \mathrm{y}$ Lactofen - $96 \mathrm{~g}$ ha $\left.{ }^{-1}\right)$. También se evaluó un tratamiento adicional sin la aplicación de ningún herbicida (Tratamiento Control). Las subdoses de 2,4-D, Lactofen e Imazetapir proporcionaron mayor altura de planta, altura de inserción de la primera vaina, ramas por planta, número de vainas y número de granos. Es necesario un nuevo ajuste en las dosis de 2,4-D, Lactofen e Imazetapir para contribuir en el futuro a incrementar la productividad de la soja.

Palabras-clave: Glycine max; 2,4-D; Lactofen; Imazetapir.

\section{Introduction}

Brazil already is considered one of the largest producers and exporters of grains in the world, especially in relation to soybean, one of the main world commodities currently (Oecd/Fao 2020; Conab, 2021). According to Conab (2021), the area planted with soybean (Glycine max) in the 2020/21 crop season was 38.4 million hectares, $4 \%$ higher that observed in the previous crop season, which allowed a record production of grains estimated at 135.5 million tons, $8.8 \%$ higher that observed in the previous crop season. This growth in both area planted and soybean production has been maintained year after year, further consolidating Brazil as the world's largest soybean producer and exporters.

Despite the increase in the cultivated area and in soybean production, the average productivity remains similar over the years. Therefore, in the 2016/17, 2017/18, 2018/19, 2019/20 and 2020/21 crop seasons, yields were 3,364; 3,359; 3,206, 3,322 and 3,523 thousand $\mathrm{kg} \mathrm{ha}^{-1}$, respectively (Conab 2017, 2018, 2019, 2020, 2021). Thus, currently, the great challenge of the farmers is to increase the productivity of soybean. One of the alternatives found is the use of plant regulators (such as herbicides applied in subdoses) (Silva et al., 2009) in order to stop the growth in plant height and to induce lateral branches, which might lead to a greater formation of reproductive nodes and, consequently, more flowers and pods per plant (Yang et al., 2021). Plant growth regulators are synthetic chemicals with an effect on plant metabolism, so they inhibit, alter, or promote physiological and biochemical processes in plants (Nagashima et al., 2010; Silva et al., 2012). Nowadays, it is one of the most widely used techniques in tropical agriculture to manage plant architecture.

The term "hormesis" was introduced by Ehrlich in 1943 to describe a phenomenon associated with chemicals that, in low doses or subdoses, show a stimulating or beneficial effect on plant development, but that in high doses show an inhibitory or toxic effect (Calabrese \& Blain, 2009). The hormonal effect of the application of subdoses of herbicides has been widely discussed and researched in order to understand the mechanism of beneficial action of several substances initially considered toxic for plant growth (Silva et al., 2009).

Most of the research found in the literature with the aim of evaluating the possible hormetic effects in plants are performed through the application of doses of glyphosate, a non-selective herbicide of systemic action of the chemical group glycine substituted. According to the authors, when applied in subdoses this herbicide promotes a beneficial effect in the growth of the shoot and root part of trapoeraba (Commelina benghalensis) and wheat (Triticum spp.) (El-Shawy \& Sharara 2011a), growth and productivity of beans (Phaseolus vulgaris) (El-Shawy \& Sharara 2011b; Silva et al., 2012; Silva et al., 2016), initial growth of sugarcane (Saccharum officinarum) (Silva et al., 2009) and increases in the sugar content and reduction in lignin content in sugarcane (Meschede et al., 2012). 
Besides glyphosate, several herbicide molecules might have other purposes than just weed control and, therefore, this subject deserves a special approach. The side effects of herbicides can be seen at normal doses or at much lower doses than recommended. For example, 2,4-D is a systemic herbicide that was originally developed as auxin, but at high doses it presents an herbicidal effect (Mortensen et al., 2012; Queiroz \& Vidal 2014). According to Miranda (2012), 2,4-D acts as a growth regulator, inducing metabolic and biochemical changes, which leads to a reduction in the growth process. Imazetapir is also a systemic herbicide of the chemical group Imidazolinone, an irreversible inhibitor of the enzyme acetolactate synthase (ALS) responsible for catalyzing the synthesis of three essential aliphatic amino acids in plants: valine, leucine and isoleucine (Melhorança \& Pereira 2000; Marchesan et al., 2010; Souto et al., 2013). Lactofen is a selective herbicide belonging to the chemical group diphenylether, promotes the inhibition of the enzyme protoporphyrin oxidase (PROTOX), compromising the formation of chlorophyll, carotenoids and membrane integrity through the generated phytotoxicity (Trezzi et al., 2011; Cesco et al., 2018).

The herbicides 2,4-D, Imazetapir and Lactofen are widely used in soybean cultivation throughout Brazil in the control of broadleaves plants (Gallon et al., 2016). On the other hand, there are few studies on the possible hormetic effects of these herbicides on the development of soybean cultivation in Brazil. Therefore, the aim of this study was to evaluate the effect of herbicide application on the development and production components of six soybean cultivars in the state of Tocantins. The hypothesis is that the use of subdoses of herbicides can promote a beneficial effect on the development and production components of soybean crops.

\section{Methodology}

The study was carried out during the 2017/18 crop season in an experimental area of Santo André Farm $\left(9^{\circ} 20^{\prime} 53.09^{\prime \prime}\right.$ S, 49 47'43.79" W), located in municipality of Caseara, state of Tocantins, Brazil (Figure 1). According to Roldão \& Ferreira (2019) and Alvares et al. (2013) the climate classification of the entire state of Tocantins is Aw (hot climate, with summer rainfall), with an average temperature of $27{ }^{\circ} \mathrm{C}$ and average annual rainfall of $1600 \mathrm{~mm}$. The altitude at the experiment site is $190 \mathrm{~m}$. The pluviometric data during the conduction of the experiment are shown in Figure 2.

Figure 1. Location of the experimental area located in municipality of Caseara, state of Tocantins, Brazil.

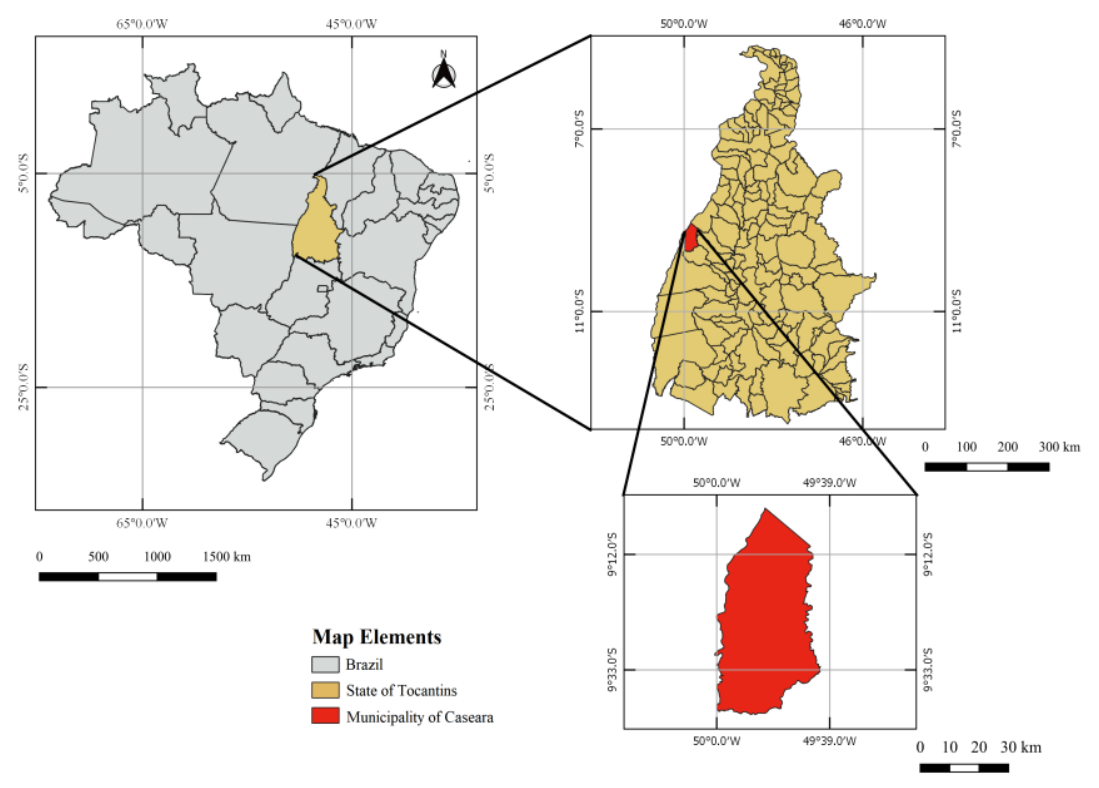

Source: Authors. 
Figure 2. Rainfall data at the experiment site form October 2017 to May 2018. Source: Maximum consulting database.

\section{RAINFALL}

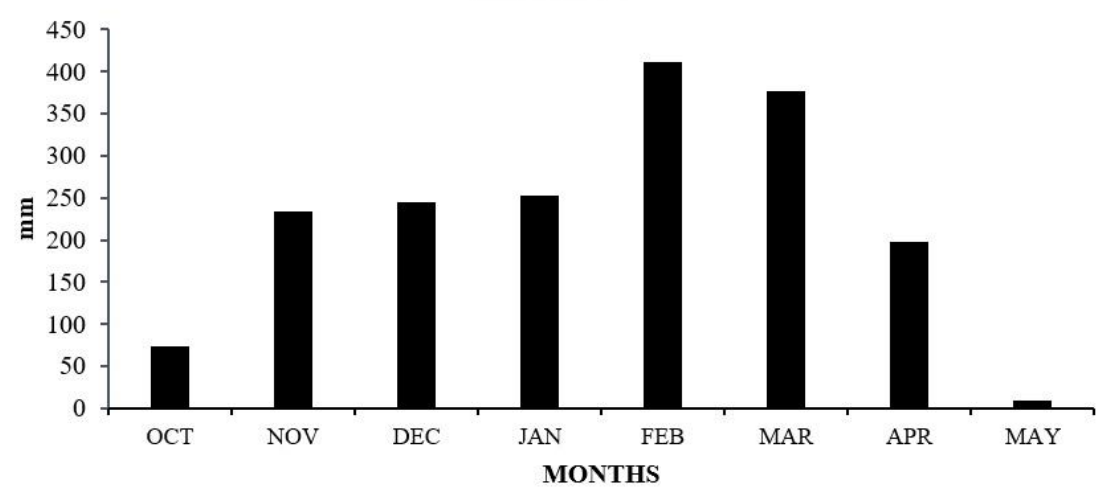

Source: Authors.

The experiment was conducted in randomized blocks with four replications. The 24 treatments were distributed in a 6 x 4 factorial scheme. The first factor was composed of six soybean cultivars (M8644 IPRO, M8372 IPRO, M8349 IPRO, M8766 RR, NS7901 RR and CD251 RR). The second factor was composed of three herbicides and their respective doses (2,4D - $40.3 \mathrm{~g} \mathrm{ha}^{-1}$; Imazetapir - $26.5 \mathrm{~g} \mathrm{ha}^{-1}$; Lactofen - $96 \mathrm{~g} \mathrm{ha}^{-1}$ ) and an additional treatment without the application of any herbicide (Control treatment) was used, totalizing four treatments. The commercial products, registered for soybean in the control of broadleaves plants that contain each herbicide used in this study were: Aminol ${ }^{\circledR} 806$, which contains $0.806 \mathrm{~kg} \mathrm{~L}^{-1}$ of 2,4-D dimethylamine; Zaphir ${ }^{\circledR}$, which contains $0.106 \mathrm{~kg} \mathrm{~L}^{-1}$ of Imazetapir and Drible ${ }^{\circledR}$, which contains $0.240 \mathrm{~kg} \mathrm{~L}^{-1}$ of Lactofen. The growth habit, maturity group and the cycle of the cultivars are described in Table 1.

Table 1. Growth habit, maturity group and cycle (days) of soybean cultivars.

\begin{tabular}{cccc}
\hline Cultivar & Growth Habit & Maturity Group & Cycle (Days) \\
\hline Msoy 8644 IPRO & Determinate & 8.6 & 120 \\
Msoy 8372 IPRO & Determinate & 8.3 & 113 \\
Msoy 8349 IPRO & Determinate & 8.3 & 112 \\
Msoy 8766 RR & Determinate & 8.7 & 120 \\
NS 79011 RR & Indeterminate & 7.9 & 110 \\
CD 251 RR & Determinate & 8.6 & 120 \\
\hline
\end{tabular}

Source: Authors.

The experimental plots were composed of four lines of $7.0 \mathrm{~m}$ long, spaced $0.50 \mathrm{~m}$ apart, making a total area of $14 \mathrm{~m}^{2}$ and a useful area of $6.5 \mathrm{~m}^{2}$, since only the two central lines were used to collect the data, disregarding $0.50 \mathrm{~m}$ from the end of each one. The soil at the experiment site was classified as Haplic Plinthosol according to the Brazilian Soil Classification System (Sousa et al., 2018). Before the installation of the experiments, the soil at the site was sampled from the 0.00-0.20-m layer, and the results of soil fertility analysis, according to the method described by Teixeira (2017), are listed in the Table 2. 
Table 2. Chemical and physical characterization of Haplic Plinthosol.

\begin{tabular}{lrlr}
\hline $\mathrm{pH}\left(\mathrm{H}_{2} \mathrm{O}\right)$ & 6.0 & Aluminium saturation $(\mathrm{m} \%)$ & 0.0 \\
Organic matter $\left(\mathrm{g} \mathrm{kg}^{-1}\right)$ & 17.0 & $\mathrm{~S}\left(\mathrm{mg} \mathrm{kg}^{-1}\right)$ & 2.0 \\
Phosphorus $\left(\mathrm{mg} \mathrm{kg}^{-1}\right)$ & 7.5 & $\mathrm{Na}\left(\mathrm{mg} \mathrm{kg}^{-1}\right)$ & 7.0 \\
Potassium $\left(\mathrm{mg} \mathrm{kg}^{-1}\right)$ & 119.0 & $\mathrm{Zn}\left(\mathrm{mg} \mathrm{kg}^{-1}\right)$ & 0.8 \\
Calcium $\left(\mathrm{cmol}_{\mathrm{c}} \mathrm{kg}^{-1}\right)$ & 2.3 & $\mathrm{~B}\left(\mathrm{mg} \mathrm{kg}^{-1}\right)$ & 0.5 \\
Magnesium $\left(\mathrm{cmol}_{\mathrm{c}} \mathrm{kg}^{-1}\right)$ & 1.5 & $\mathrm{Cu}\left(\mathrm{mg} \mathrm{kg}^{-1}\right)$ & 1.8 \\
Exchangeable aluminum $\left(\mathrm{cmol}_{\mathrm{c}} \mathrm{kg}^{-1}\right)$ & 0.0 & $\mathrm{Fe}\left(\mathrm{mg} \mathrm{kg}^{-1}\right)$ & 110.0 \\
Potential acidity $(\mathrm{H}+\mathrm{Al})\left(\mathrm{cmol}_{\mathrm{c}} \mathrm{kg}^{-1}\right)$ & 1.9 & $\mathrm{Mn}\left(\mathrm{mg} \mathrm{kg}^{-1}\right)$ & 41.5 \\
Sum of bases $(\mathrm{Ca}+\mathrm{Mg}+\mathrm{K})\left(\mathrm{cmol}_{\mathrm{c}} \mathrm{kg}^{-1}\right)$ & 4.1 & $\mathrm{Sand}\left(\mathrm{g} \mathrm{kg}^{-1}\right)$ & 590.0 \\
Cation Exchange Capacity $\left(\mathrm{cmol}_{\mathrm{c}} \mathrm{kg}^{-1}\right)$ & 6.0 & Silt $(\%)$ & 90.0 \\
Base saturation $(\mathrm{V} \%)$ & 68.0 & $\mathrm{Clay}(\%)$ & 320.0 \\
\hline
\end{tabular}

Source: Authors.

Sowing of soybean cultivars was carried out on December 14, 2017 in an area under the conventional planting system with the aid of a John Deere tractor model $6190 \mathrm{~J}$ and John Deere planter model 2117 CCS 15 rows. The spacing used was 45 $\mathrm{cm}$ in all cultivars. Sowing fertilization consisted of $175 \mathrm{~kg} \mathrm{ha}^{-1}$ of MAP and subsoil fertilization was performed 30 days after the emergency, with $135 \mathrm{~kg} \mathrm{ha}^{-1}$ of $\mathrm{KCl}$, distributed with the aid of a Case Farmall 95 Tractor and Stara model Hercules 15000 stainless steel spreader. In the seed treatment (TS), the insecticide chlorantraniliprole $\left(0.01 \mathrm{~kg} \mathrm{ha}^{-1}\right.$ of i.a.), the fungicide with the active principles thiophanate-methyl $\left(0.028 \mathrm{~kg} \mathrm{ha}^{-1}\right.$ of i.a.) and fluzinam $\left(0.0042 \mathrm{~kg} \mathrm{ha}^{-1}\right.$ of i.a. $)$, as well as organomineral fertilizer and micronutrient, such as zinc $(\mathrm{Zn})$ and copper $(\mathrm{Cu})$, were used.

The treatments were applied in the phenological stage V4, with the help of the motorized knapsack sprayer, with a three-meter bar, brown conical nozzle Magnojet M053 and 80 mesh, with a syrup volume of $150 \mathrm{~L} \mathrm{ha}^{-1}$. According to Tironi et al. (2009), the phenological stage V4 is when the process of symbiosis begins, which is considered the best stage to make use of growth regulators. In this moment, the number of nodes per plant is defined and it is the moment when there is a higher concentration of auxin in the apex of the plants (Liu et al., 2010).

Harvest was carried out in two stages. On April 1st, 2018, for cultivars NS7901 RR, M8342IPRO and M8349 IPRO, as well as on April 8st, 2018, for cultivars M8644 IPRO, M8766 RR and CD251 RR. The plots were harvested and separated individually, and four plants from the two central rows of each plot were randomly chosen. The agronomic and production characteristics were evaluated: Plant height $(\mathrm{PH}, \mathrm{cm})$, first pod insertion height (FPIH, cm), branches per plant $(\mathrm{BP})$, internodes per plant (IP), pods per plant (PP), grains per plant (GP) and thousand grain weight (TGW, g).

PH was measured with a graduated ruler from the ground. The FPIH was measured with a graduated ruler from the ground to the first pod of the plant. For BP, IP and PP were counted manually on each plant. To determine GP and TGW, the soybean plants were manually screened (to avoid damage and partial loss of seeds), cleaning the impurities and keeping only the grains, where later they were counted manually and weighed on a scale with three decimal place accuracy. After weighing, the humidity (\%) of each plot was measured with the aid of the portable grain moisture measuring equipment (Gehaka-G300) and later the readjustment of $13 \%$ of humidity was made in order to have a better accuracy of the final weight of the grains of each plot.

The data were submitted to analysis of variance for each tested cultivar. The comparison of means was performed by Tukey's Test at a 5\% probability level using Sisvar software version 5.6 (Ferreira 2011). The Sigma Plot 12.5 (Systat Software Inc., San Jose, CA, USA) softwares were employed for making the graphics.

\section{Results and Discussion}

The treatments strongly influenced the characteristics evaluated in this study. According to the analysis of variance (Table 3), a significant response $(\mathrm{p}<0.01)$ is observed for the sources of cultivar variation, herbicides and the interaction 
among them for all agronomic and production characteristics evaluated in this study, except for FPIH, which obtained no significant effect for the source of herbicide variation. Since this is a field experiment, the present work obtained VS (\%) ranging from low (8.24) to very high (27.7), according to Carvalho et al. (2003) for soybean cultivation.

Table 3. Summary of the analysis of variance for the characteristics Plant height (PH), first pod insertion height (FPIH), branches per plant (BP), internodes per plant (IP), pods per plant (PP), grains per plant (GP) and thousand grain weight (TGW) soybean plant submitted to herbicide application with different active ingredients.

\begin{tabular}{|c|c|c|c|c|c|c|c|c|}
\hline VS & $\mathrm{DF}$ & $\mathrm{PH}$ & FPIH & $\mathrm{BP}$ & IP & PP & GP & TGW \\
\hline Cultivar (C) & 5 & $373.3^{\text {** }}$ & $87.8^{* *}$ & $38.1^{* *}$ & $46.7^{\text {** }}$ & $4023.8^{* * *}$ & $15250.1^{\text {** }}$ & $4439.0^{\text {** }}$ \\
\hline Herbicide $(\mathrm{H})$ & 3 & $142.4^{\text {** }}$ & $13.7^{\mathrm{ns}}$ & $9.3^{* *}$ & $22.3^{* *}$ & $465.1^{* *}$ & $1585.6^{* *}$ & $167.7^{\text {** }}$ \\
\hline $\mathrm{C} \times \mathrm{H}$ & 15 & $395.4^{* *}$ & $37.1^{* *}$ & $5.9^{* *}$ & $5.3^{* *}$ & $246.2^{* *}$ & $1209.1^{* *}$ & $689.1^{* *}$ \\
\hline Block & 3 & 65.9 & 0.34 & 4.7 & 9.2 & 1.0 & 742.0 & 2520.4 \\
\hline Residue & 69 & 22.7 & 10.0 & 1.9 & 2 & 64.5 & 274.3 & 321.1 \\
\hline Mean & & 58.0 & 17.2 & 5.0 & 11.0 & 42.4 & 91.2 & 119.1 \\
\hline VS $(\%)$ & & 8.24 & 18.44 & 27.7 & 13.65 & 19.0 & 18.7 & 14.6 \\
\hline
\end{tabular}

VS -Variation source; DF - Degree of freedom; **Significant at $1 \%(p<0.01)$ probability level; * Significant at 5\% $(p \leq 0.05)$ probability level; ns Not significant by the Tukey test. Source: Authors.

The application of subdoses of the herbicides significantly influenced the PH of the tested soybean cultivars (Figure 3A). It can be observed that the application of 2,4-D provided the highest PH when applied to cultivars M8372 IPRO and CD251 RR. For these cultivars, the maximum PH values were 82 and $73 \mathrm{~cm}$, respectively, which represent an increase of 66 and 59\% when compared with the control treatment. However, applications of 2,4-D, Imazetapyr and Lactofen in the M8644 IPRO and M8766 RR cultivars and application of 2,4-D in the M8349 IPRO and NS7901 RR acted as growth inhibitor in these cultivars and provided significant reduction of 19, 15, 8 and 24\% in PH in relation to the control treatment for each cultivar.

The evaluation of PH is of great importance when evaluating the application of herbicide subdoses (Silva et al., 2012). The increase in PH observed in this study with the application of 2,4-D can be explained by its performance as an auxin-type plant growth regulator when applied in subdoses, which can lead to abnormal plant growth and may affect production components (Mortensen et al., 2012). On the other hand, the reduction in PH after application of Imazetapyr and Lactofen was also observed by Gallon et al. (2016) and Bundt et al. (2010), using $144 \mathrm{~g} \mathrm{ha}^{-1}$ and $75 \mathrm{~g} \mathrm{~L}^{-1}$ in non-resistant soybean and rice crops, respectively. This result confirms the deleterious effect that these herbicides have on PH of some crops even in subdoses (96 and $26.5 \mathrm{~g} \mathrm{ha}^{-1}$ ), as shown in the present study. 
Figure 3. Plant Height (A) and First Pod Insertion Height (B) of soybean cultivars: C1 - M8644 IPRO, C2 - M8372 IPRO, C3 - M8349 IPRO, C4 - M8766 RR, C5 - NS7901 RR and C6 - CD251 RR, submitted to herbicide subdoses.
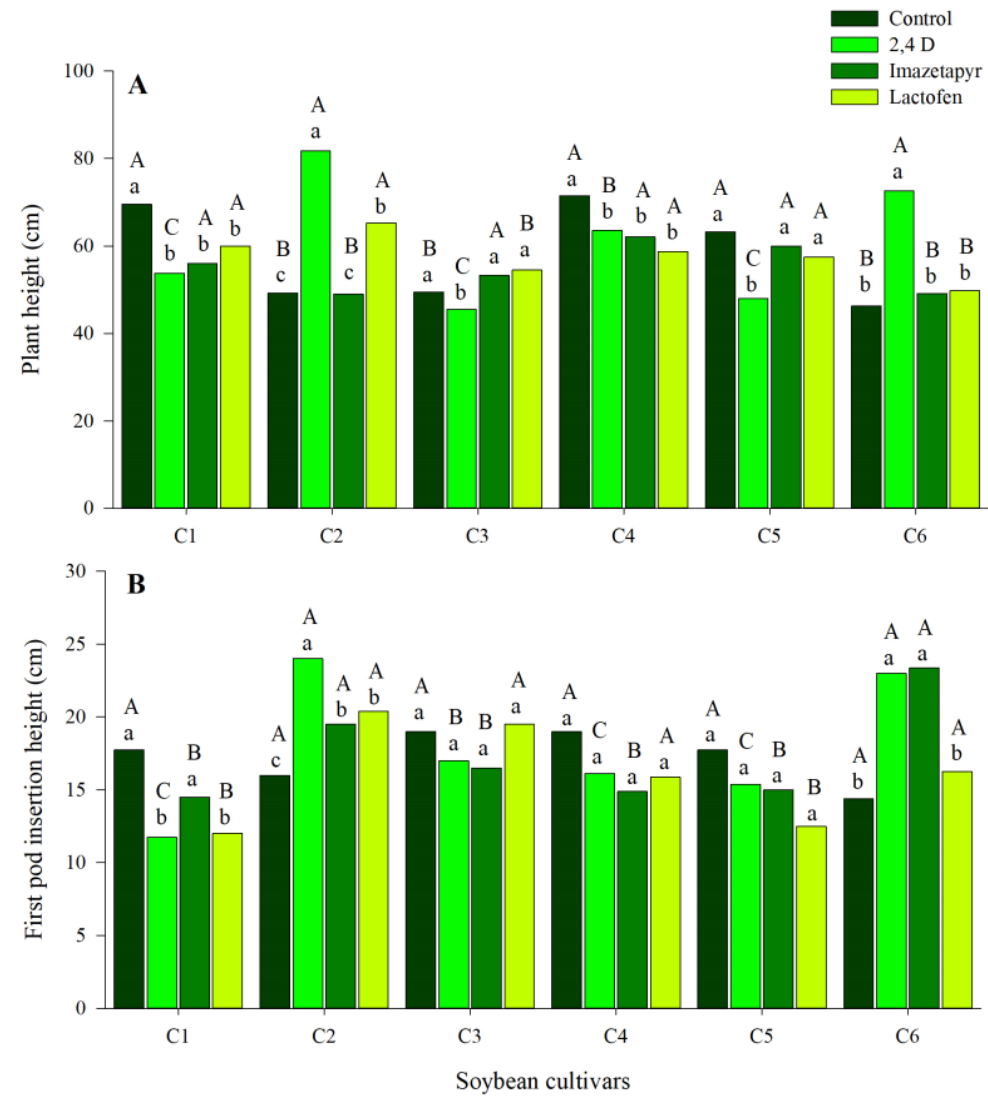

Note. Distinct letters, lower-case compare herbicides applied and upper-case compare soybean cultivars, indicate significant difference $5 \%$ of probability by Tukey test. Source: Authors.

The increase in PH caused by the application of 2,4-D also caused an increase in FPIH of the cultivars M8372 IPRO and CD251RR. This result was also achieved with the application of Imazetapyr in the CD251 RR cultivar (Figure 3B). The application of 2,4-D and Imazetapyr allowed an average of $24 \mathrm{~cm}$ of FPIH to be achieved for these cultivars, an increase of $59 \%$ when compared to the control treatment. On the other hand, the reduction in PH caused by the application of 2,4-D, Imazetapyr and Lactofen mainly on the M8644 IPRO cultivar led to an average reduction in FPIH of 33\% compared to the control treatment. For the other cultivars, the application of herbicides did not provide a significant effect on FPIH.

The opposite result was observed by Silva et al. (2012). These authors did not observe significant difference in FPIH after application of glyphosate underdoses between 0 and $40 \mathrm{~g} \mathrm{ha}^{-1}$ of i.a. in three bean cultivars. According to Amorim et al. (2011) and Chioderoli et al. (2012), the increase in FPIH does not become advantageous and may reflect on productivity, the ideal is that it is inserted at least $12 \mathrm{~cm}$ from the soil. The values observed for M8372 IPRO and CD251 RR (Figure 3B) after application of 2,4-D and Imazetapyr are above this value and may become a negative characteristic. The opposite result can be observed when applying 2,4-D, Imazetapyr and Lactofen to the M8644 IPRO cultivar, which left the FPIH close to the ideal, thus not causing losses due to deficient cutting height.

A significant increase for BP is observed in the M8644 IPRO cultivar after the application of 2,4-D, Imazetapyr and Lactofen, as well as for the M8372 IPRO cultivar after the application of 2,4-D and Lactofen (Figure 4A). For the M8644 IPRO cultivar, the application of herbicides reached mean values of seven branches, which represents a 93\% increase in relation to the control (three branches), while for the M8372 IPRO there is a mean value of five branches, a mean increase of 
$54 \%$ in relation to the control (three branches). For the other cultivars there was also an increase in BP after the application of herbicides, but this increase was not significant. The increase in BP for M8644 IPRO was already expected because these cultivars also showed a reduction in PH and for FPIH when submitted to herbicide application (Figure 3), which may have contributed to this result.

On the other hand, the significant increase in BP for the M8644 IPRO did not promote an increase in IP (Figure 4B). The highest IP was obtained in M8372 IPRO, NS7901 RR and D251 RR through the application of 2,4-D and Lactofen. These cultivars obtained on average 12, 13 and 14 internodes, an increase of 50, 30 and 22\% in relation to the control treatment in each cultivar. For the other cultivars there was no statistical difference in IP after the application of herbicides. The increase in BP of the M8372 IPRO cultivar after application of Lactofen (Figure 4A) contributed to the increase in IP. The results for BP and IP were already expected, because, according to Gallon et al. (2016), the application of some herbicides paralyzes the vegetative growth of the plants, breaking the apical dominance inducing directly the increase in the branching of the plants and the number of internodes, which was observed in the present study, mainly for the cultivar M8372 IPRO.

Figure 4. Branches per plant (A) and Internodes per plant (B) from soybean cultivars: C1 - M8644 IPRO, C2 - M8372 IPRO, C3 - M8349 IPRO, C4 - M8766 RR, C5 - NS7901 RR and C6 - CD251 RR, submitted to herbicide subdoses.
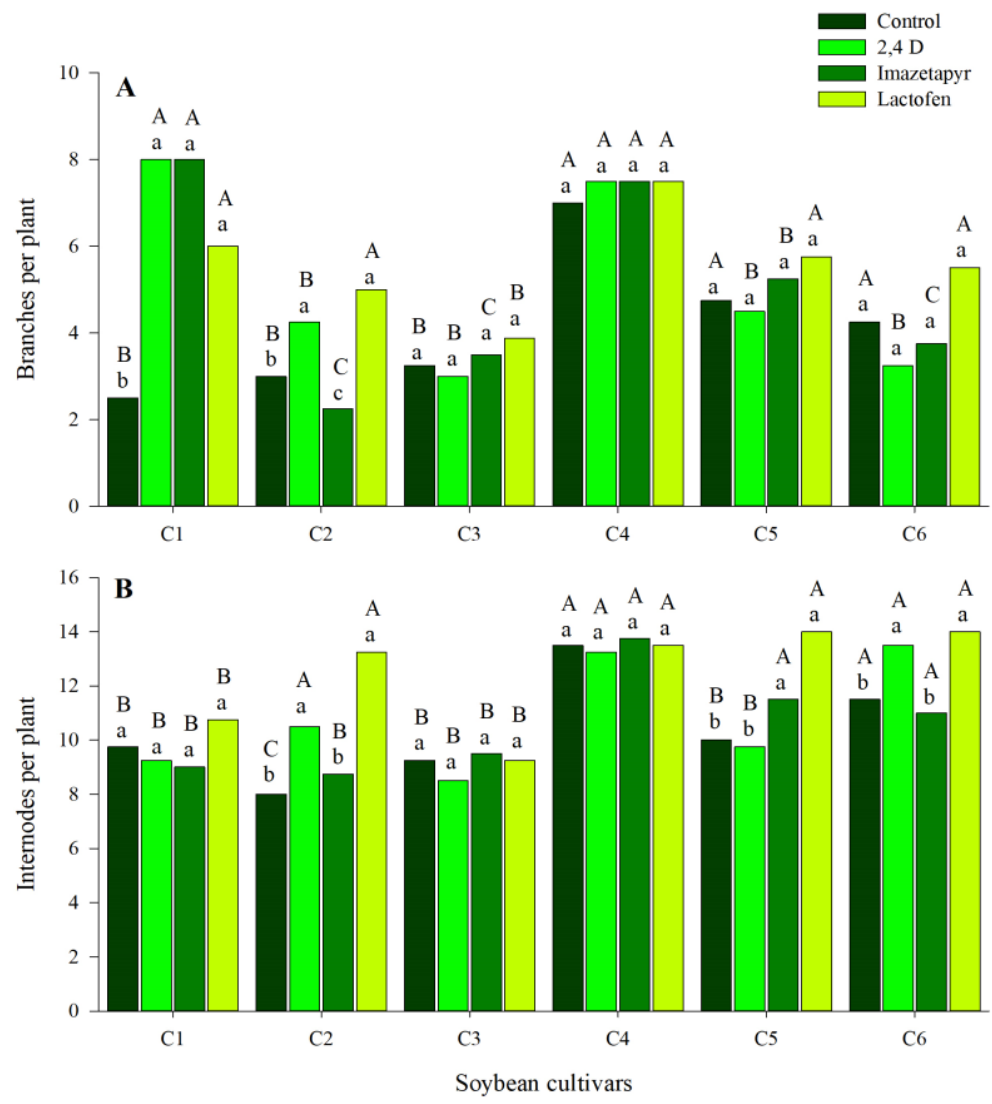

Note. Distinct letters, lower-case compare herbicides applied and upper-case compare soybean cultivars, indicate significant difference 5\% of probability by Tukey test. Source: Authors.

For PP, it is observed that the application of 2,4-D, Imazetapyr and Lactofen provided good results mainly for the cultivars M8644 IPRO, M8766 RR and NS7901 RR, as well as 2,4-D and Imazetapyr for CD251 RR (Figure 5A). These cultivars obtained an average increase of 61, 17 and 49 and 59\% in relation to the control treatment in each cultivar. The results for GP remained proportional to the results obtained for PP (Figure 5B). However, there was a significant difference 
only for the M8644 IPRO cultivar with the 2,4-D, Imazetapyr and Lactofen application, as well as for the NS7901 RR cultivar after the application of Lactofen and for the CD251 RR cultivar after the application of Imazetapyr and Lactofen. Thus, increases in GP of 66, 81 and 57\% are observed in relation to the control of each tested cultivar.

It is important to note that the application of 2,4-D, Imazetapyr and Lactofen herbicides reduced PH and FPIH, which resulted in a significant increase in BP and consequently increased PP and GP per plant mainly of the M8644 IPRO cultivar, showing a positive hormone effect of the application of subdoses of these herbicides. The results found for PP and GP in the present study are opposite to those found by Silva et al. (2012), Silva et al., (2016) and Cabral (2019). These authors concluded that the application of herbicide subdoses under the culture of beans and soybean did not provide significant increase in PP and NG. However, the same did not occur with the results obtained by Gitti et al. (2011), in rice crop, where it was possible to observe a significant increase in the number of total grains and grenades per panicle with the increase in glyphosate subdoses.

Figure 5. Number of pods per plant (A) and grains per plant (B) of soybean cultivars: C1 - M8644 IPRO, C2 - M8372 IPRO, C3 - M8349 IPRO, C4 - M8766 RR, C5 - NS7901 RR and C6 - CD251 RR, submitted to herbicide subdoses.
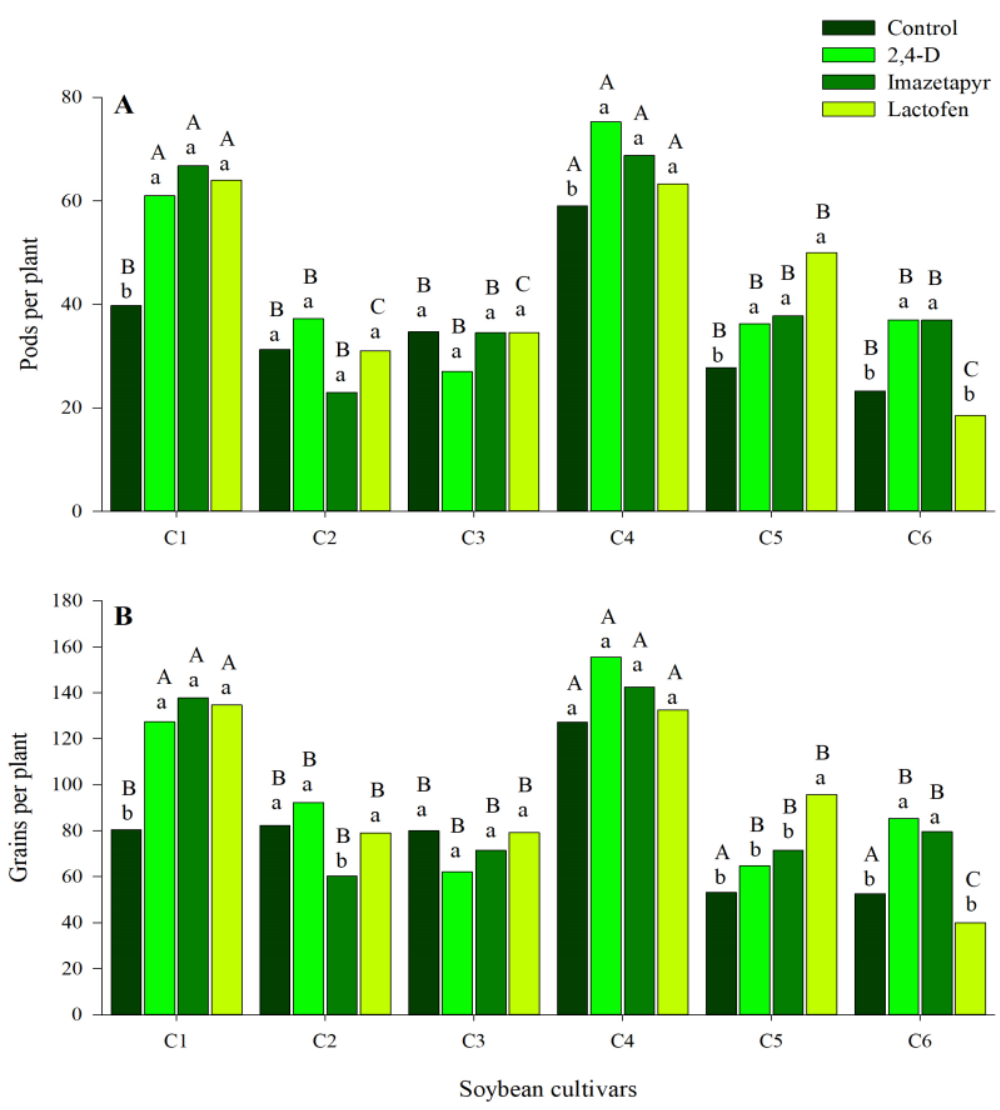

Note. Distinct letters, lower-case compare herbicides applied and upper-case compare soybean cultivars, indicate significant difference $5 \%$ of probability by Tukey test. Source: Authors.

As for TGW, it is observed that the application of the 2,4-D, Imazetpyr and Lactofen herbicides did not result in a significant increase for this characteristic in all tested soybean cultivars compared to the control treatment (Figure 6). On the other hand, there was a 17\% reduction in the TGW of the M8372 IPRO cultivar with the application of Imazetpyr, for the NS7901 RR and M8644 IPRO cultivars there was also a reduction in the TGW, but it was not significant.

The cultivars that obtained the highest averages for TGW, regardless of the applied herbicide, were M8349 IPRO, M8644 IPRO, NS7901 RR and CD251 RR reaching 138.8, 128.8, 125.5 and $124.5 \mathrm{~g}$, respectively. This result can be explained 
by the fact that these cultivars develop fewer pods and fewer grains (Figure 3), in which a higher source/drain ratio results in a higher grain weight. It corroborates the results found by Silva et al. (2012), Silva et al. (2016) and Cabral (2019) for the cultivation of beans and soybean under application of subdoses of herbicides.

Figure 6. Thousand-grain weight of soybean cultivars: C1 - M8644 IPRO, C2 - M8372 IPRO, C3 - M8349 IPRO, C4 - M8766 RR, C5 - NS7901 RR and C6 - CD251 RR, submitted to herbicide subdoses.

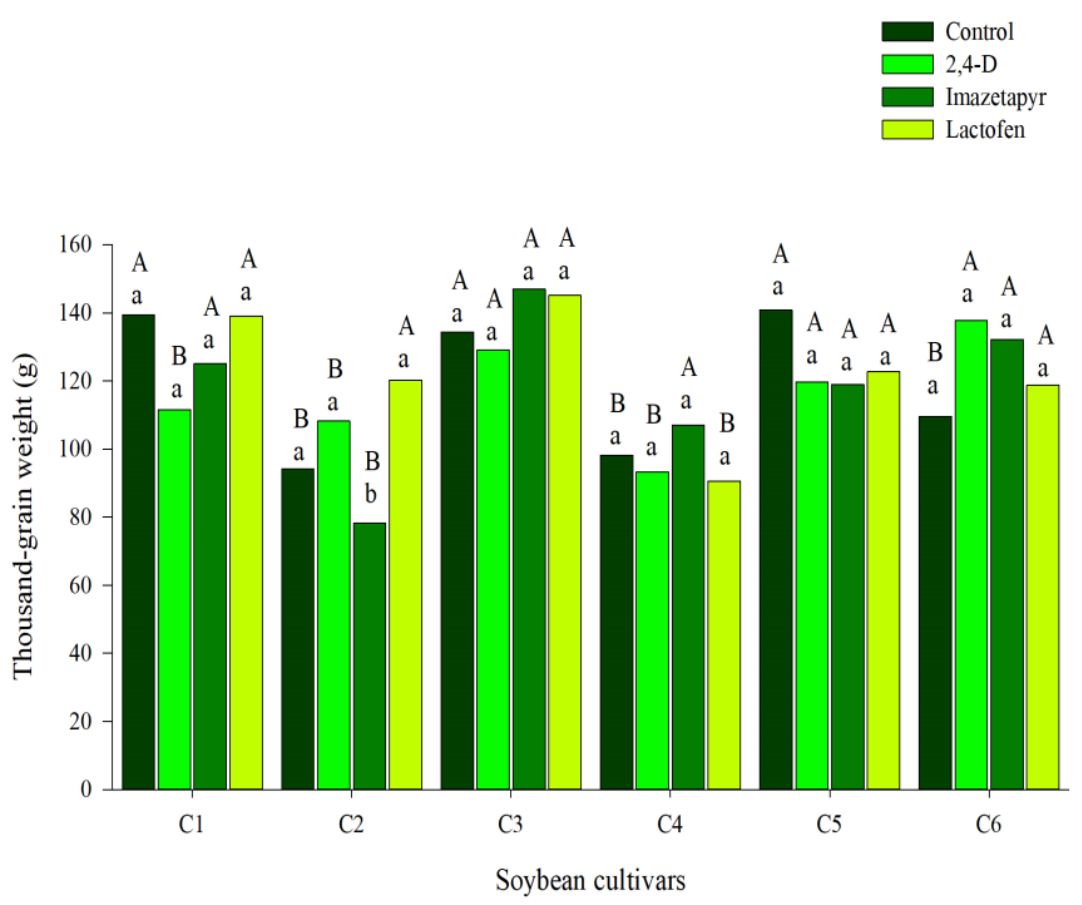

Note. Distinct letters, lower-case compare herbicides applied and upper-case compare soybean cultivars, indicate significant difference 5\% of probability by Tukey test. Source: Authors.

When comparing the responses of each soybean cultivar in the control treatment, there was high response variability for PH, FPIH, BP, IP, PP, GP and TGW among the cultivars, with no specific response pattern occurring. These results can be explained by the genetic characteristics related to each soybean cultivar (Silva et al., 2012).

The application of subdoses of 2,4-D, Lactofen and Imazetapyr as plant growth regulators has enabled positive and promising responses to the characteristics related to the vegetative development of soybean cultivars that directly influenced the production components, with the exception of TGW. Therefore, farmers should always pay attention to new possibilities of using plant growth regulators, among them the use of subdoses of herbicides through the possible horticultural effects that they can provide to crops, which may contribute in the future to increase the productivity of soybean crops.

\section{Conclusion}

The application of subdoses of 2,4-D, Lactofen and Imazetapyr acted as plant growth regulators and provided positive and promising results for Plant height, first pod insertion height and branches per plant characteristics, resulting in the increase of pods per plant and grains per plant, mainly from the soybean cultivar M8644 IPRO, confirming the hormetic effect of the use of subdoses of these herbicides in soybean cultivation.

No significant increase was observed for the thousand grain weight production component after the application of subdoses of 2,4-D, Lactofen and Imazetapyr, regardless of the tested soybean crop. Nevertheless, a small reduction was 
observed in this characteristic with the use of these herbicides. With these results we have that a new adequacy in the doses of 2,4-D, Lactofen and Imazetapyr is necessary to contribute in the future to the increase of the productivity of the soybean culture. However, more studies are needed regarding the physiological behavior of soybean plants as a function of the application of these herbicides as growth regulators.

\section{Acknowledgments}

The authors gratefully thank the Coordination of Improvement of Higher Education Personnel (CAPES) for granting the scholarship to the first author, and the National Council of Scientific and Technological Development (CNPq).

\section{References}

Alvares, C. A., Stape, J. L., Sentelhas, P. C., Moraes, G. J. L. \& Sparovek, G. (2013). Köppen's climate classification map for Brazil. Meteorologische Zeitschrift, 22(6), 711-728. https://doi.org/10.1127/0941-2948/2013/0507

Amorim, F. A., Hamawaki, O. T., Sousa, L. B., Lana, R. M. Q. \& Hamawaki, C. D. L. (2011). Sowing season in the productive potential of soybean in Uberlândia - MG. Semina: Ciências Agrárias, 32(1), 1793-1802. https://doi.org/10.5433/1679-0359.2011v32Suplp1793

Bundt, A. C., Avila, L. A., Agostinetto, D., Nohatto, M. A., Souto, K.M. \& Senseman, S.A. (2010). Depth of location of imazetapir + imazapique herbicide in the soil on phytotoxicity in non-resistant rice plants. Ciência Rural, 40(9). https://doi.org/10.1590/S0103-84782010000900003

Cabral, E. M. A. (2019). Uso de reguladores de crescimento na cultura de soja. Universidade de São Paulo / Escola Superior de Agricultura "Luiz de Queiroz”. 72p. Dissertação de Mestrado.

Calabrese, E. J. \& Blain, R. B. (2009). Hormesis and plant biology. Environmental Pollution, 157(1), 42-48. https://doi.org/10.1016/j.envpol.2008.07.028

Carvalho, C. G. P., Arias, C. A. A., Toledo, J. F. F., Almeida, L. A., Kiihl, R. A. S., Oliveira, M. F., Hiromoto, D. M. \& Takeda, C. (2003). Proposed classification of the coefficients of variation in relation to productivity and plant height of soybean. Pesquisa agropecuária brasileira, 38(2), 187-193. https://doi.org/10.1590/S0100-204X2003000200004

Cesco, V. J. S. (2018). Hormesis de glyphosate no desenvolvimento vegetativo e reprodutivo de biótipos de Conyza spp. Universidade Estadual Paulista "Júlio de Mesquita Filho" - UNESP. Botucatu. Dissertação de Mestrado.

Chioderoli, C. A., Silva, R. P., Noronha, R. H. F., Cassia, M.T. \& Santos, E. P. (2012). Grain losses and straw distribution in mechanized soybean harvesting. Revista Bragantia, 71(1), 112-121. https://doi.org/10.1590/S0006-87052012005000003

Conab (Companhia Nacional De Abastecimento). Acompanhamento da safra brasileira de grãos, safra 2016/17. Décimo segundo levantamento, Brasília, 148p. https://www.conab.gov.br/info-agro/safras/graos/boletim-da-safra-de-graos?start=40

Conab (Companhia Nacional De Abastecimento). Acompanhamento da safra brasileira de grãos, safra 2017/18. Décimo segundo levantamento, Brasília, 125p. https://www.conab.gov.br/info-agro/safras/graos/boletim-da-safra-de-graos?start=40

Conab (Companhia Nacional De Abastecimento). Acompanhamento da safra brasileira de grãos, safra 2018/19. Décimo segundo levantamento, Brasília, 47p. https://www.conab.gov.br/info-agro/safras/graos/boletim-da-safra-de-graos?start=40 21

Conab (Companhia Nacional De Abastecimento). Acompanhamento da safra brasileira de grãos, safra 2019/20. - Décimo segundo levantamento, Brasília, 68p. https://www.conab.gov.br/info-agro/safras/graos/boletim-da-safra-de-graos?start=40

Conab (Companhia Nacional De Abastecimento). Acompanhamento da safra brasileira de grãos, safra 2020/21. Sétimo levantamento, Brasília, 18p. https://www.conab.gov.br/info-agro/safras/graos/boletim-da-safra-de-graos?start=40 21

El-Shahawy, F. A. \& Sharara, F. A. A. (2011a). Hormetic effect of glyphosate on wheat and associated weeds. International Journal of Academic Research, $3(3), 520-523$.

El-Shahawy, F. A. \& Sharara, F. A. A. (2011b). Hormesis influence of glyphosate in between increasing growth, yield and controlling weeds in faba bean. Journal of American Science, 7, 139-144.

Oecd/Fao. Agricultural Outlook 2020-2029. FAO. 2020. Rome/OECD Publishing, Paris. https://doi.org/10.1787/1112c23b-en

Ferreira, D. F. (2011). SISVAR: a computer statistical analysis system. Ciência e Agrotecnologia, 35(6), 1039- 1042. https://doi.org/10.1590/S141370542011000600001

Gallon, M., Buzzello, G. L., Trezzi, M. M., Diesel, F. \& Silva, H. L. (2016). Action of protox inhibitor herbicides on the development, lodging and productivity of soybean. Revista Brasileira de Herbicidas, 15(16), 232 - 240. https://doi.org/10.7824/rbh.v15i3.471

Gitti, D. C., Arf, O., Peron, I. B. G., Portugal, J. R., Corsini, D. C. D. C. \& Rodrigues, R. A. F. (2011). Glyphosate as a growth regulator in upland rice. Pesquisa Agropecuária Tropical, 41(4), 500-507. https://doi.org/10.5216/pat.v41i4.10160 
Liu, B., Liu, X., Wang, X., Jin, J., Herbert, S.J. \& Hashemi, M. (2010). Responses of soybean yield and yield components to light enrichment and planting density. International Journal Plant Production, 4(1), 1-9.

Marchesan, E., Santos, F. M., Grohs, M., Avila, L. A., Machado, S. L. O., Senseman, S. A., Massoni, P. F. S. \& Sartori, G. M. S. (2010). Carryover of imazetapir and imazapique to nontolerant rice. Weed Technology, 24(1), 6-10. https://doi.org/10.1614/WT-08-153.1

Melhorança, A. L. \& Pereira, F. A. (2000). Eficiência do herbicida Lactofen no controle de euphorbia heterophylla resistente aos herbicidas inibidores da enzima acetolactato sintase (ALS). Revista Brasileira de Herbicida, 1(1), 53-56. https://doi.org/10.7824/rbh.v1i1.315

Meschede, D. K. I., Velini, E. D., Carbonari, C. A. \& Moraes, C. P. (2012). Lignin and cellulose contents in sugarcane plants as a function of ripener application. Planta daninha, 30(1), 121-127. https://doi.org/10.1590/S0100-83582012000100014

Miranda, F. F. R. (2012). Efeito da frutificação induzida por 2,4-D em características agronômicas dos frutos de abóbora 'tetsukabuto'. Universidade Federal do Tocantins/UFT, Gurupi. 62p. Dissertação de Mestrado.

Mortensen, D. A., Egan, J. F., Maxwell, B. D., Ryan, M. R. \& Smith, R. G. (2012). Navigating a critical juncture for sustainable weed management. Bioscience, 62(1), 75-84. https://doi.org/10.1525/bio.2012.62.1.12

Nagashima, G. T., Miglionanza, E., Marur, C. J., Yamaoka, R. S., Barros, A. S. R. \& Marchiotto, F. (2010). Physiological quality of cotton seeds soaked in mepiquat chloride solution. Ciência e Agrotecnologia, 34(3), 681-687. https://doi.org/10.1590/S1413-70542010000300022

Queiroz, A. R. S. \& Vidal, R. A. (2014). The development of herbicide tolerant crops dichlorophenoxy acetate: review of literature. Planta Daninha, 32(3), 649-654. https://doi.org/10.1590/S0100-83582014000300021

Roldão, A. F. \& Ferreira, V. O. (2019). Climatologia do Estado do Tocantins - Brasil. Caderno de Geografia, 29(59). https://doi.org/10.5752/P.23182962.2019v29n59p1161

Silva, M. A., Aragão, N. A., Barbosa, M. A., Jeronimo, E. M. \& Carlin, S. D. (2009). Hormonal effect of glyphosate on the initial development of sugarcane. Bragantia, 68, 973-978. https://doi.org/10.1590/S0006-87052009000400017

Silva, J. C. (2012). Efeito hormese de glyphosate em feijoeiro. Pesquisa Agropecuaria Tropical, 42(3), 295-302. https://doi.org/10.1590/S198340632012000300008

Silva, R. A., Matsumoto, S. N., Barbosa, G. M., Costa, R. Q. \& Oliveira, M. N. (2012). Aplicação de subdoses de glyphosate na fase de estabelecimento da cultura da soja e do milho. Enciclopédia biosfera, 8(15), 140.

Silva, J. C., Gerlach, G. A. X., Rodrigues, R. A. F. \& Arf, O. (2016). Influence of low doses and application times on the hormetic effect of glyphosate on bean. Revista de la Facultad de Agronomía, 115, 2, 191-199.

Souto, K. M., Jacques, R. J. S., Avila, L. A., Machado, S. L. O., Zanella, R. \& Refatti, J. P. (2013). Biodegradation of imazetapir and imazapique herbicides in rhizospheric soil of six plant species. Ciência Rural, 43(10), 1790-1796. https://doi.org/10.1590/S0103-84782013001000010

Teixeira, P. C., Donagema, G. K., Fontana, A. \& Teixeira, W. G. (2017). Manual de métodos de análise do solo, 3rd ed. Brasília: Embrapa. 573p.

Tironi, S. P., Reis, M. R., Galon, L., Freitas, M. A. M., Costa, M. D., Silva, A. A., Barbosa, M. H. P. \& Peternelli, L. A. (2009). Action of herbicides on the activity of phosphate solubilizing bacteria from sugarcane rhizosphere. Planta Daninha, 27(4), 747-754. https://doi.org/10.1590/S0100-83582009000400013

Trezzi, M. M., Xavier, E., Vidal, R. A., Portes, E. D. S., Vottri, M. \& Lamego, F. P. (2011). Rapid leaf dip test of Euphorbia heterophylla for confirmation of resistance to protox- and ALS-inhibiting herbicides. Planta Daninha, 29(4), 901-912. https://doi.org/10.1590/S0100-83582011000400021

Yang, Y., Lei, Y., Bai, Z., Wei, B., Zhang, H. \& Zhang, R. (2021). Physical mapping and candidate gene prediction of branch number on the main stem in soybean [Glycine max (L.) Merr.]. Genetic Resources and Crop Evolution, 68, 2907-2921. https://doi.org/10.1007/s10722-021-01163-y 